\title{
Internal Push Factors and External Pull Factors and Their Relationships with Lecturers' Turnover Intention
}

\author{
Sudhashini Nair ${ }^{1}$, Lim Yet Mee $^{2} \&$ Aik Nai Cheik ${ }^{2}$ \\ ${ }^{1}$ Faculty of Business, Accounting and Management, SEGi University, Kota Damansara, Selangor, Malaysia \\ ${ }^{2}$ Faculty of Accountancy and Management, University Tunku Abdul Rahman, Sungai Long, Selangor, Malaysia \\ Correspondence: Sudhashini Nair, Faculty of Business, Accounting and Management, SEGi University, Kota \\ Damansara, 47810, Petaling Jaya, Selangor, Malaysia. E-mail: sudhashini@segi.edu.my
}

Received: August 30, 2016

doi:10.5539/ijbm.v11n12p110

\author{
Accepted: October 28, $2016 \quad$ Online Published: November 20, 2016 \\ URL: http://dx.doi.org/10.5539/ijbm.v11n12p110
}

\begin{abstract}
The globalization of the higher education has resulted in the rise of private universities in Malaysia. As it is the aim of the country to be an international hub for higher education, the role of lecturers has become pivotal in the success of this industry. Literature has indicated that internal push factors such as role stress factors and attraction to various external factors may have a significant effect on employees' turnover intention. This study examines the impact of three internal push factors--role overload, role ambiguity, role conflict--and four external pull factors--job opportunity, compensation, working location, and university image--on lecturers' turnover intention. Data were obtained from 401 lecturers of private universities via self-administered questionnaires and were analyzed using structural equation modeling. The results of this study reveal that internal role overload, role ambiguity, role conflict and external working location have a significant relationship with lecturers' turnover intention respectively. The findings indicate that internal push factors play a much more significant role than external pull factors on lecturers' turnover intention. Implications of the research findings were discussed.
\end{abstract}

Keywords: turnover intention, internal push factors, role overload, role ambiguity, role conflict, external pull factors, job opportunity, compensation, working location, university image

\section{Introduction}

\subsection{The Higher Education Industry}

In the year of 2010, Malaysia ranked 11th place worldwide as a destination for international students. The Ministry of Higher Education Malaysia (MOHE) recorded a total number of 80,919 international students from more than 20 countries in that year. In the year of 2013, the total number of international students increased to 135,502 from more than 160 countries. Out of this number, 74,996 international students were studying in the private institutes of higher education ("Malaysia has one of the highest", 2015). The education sector contributed approximately RM27 billion, which is $4 \%$ of the country's gross national income (MOHE, 2015). The Malaysian government continues to expand its higher education sector to meet its target of becoming a high-income nation by 2020 .

Although the number of private colleges and universities in Malaysia has increased greatly for the past decade, the number of lecturers in these higher institutes of education has decreased from 32,992 in 2010 to 24,476 lecturers in 2013 (MOHE, 2013). The decrease in the number of lecturers may be due to the high turnover of lecturers. The turnover rate in Malaysian education sector was at $29.28 \%$ from July 2010 to July 2011, ranking third place after the information technology/communication and the hotel/restaurant sectors (Choong, Keh, \& Tan, 2013). Furthermore, the turnover rate in private universities ranged from $12 \%$ to $37 \%$ over the period from 1997 to 2011 (Abdullah Hashim \& Mahmood, 2011; Amin, 2002).

The high turnover of lecturers denotes that the private universities are experiencing a loss of talent required to mold the future workforce of Malaysia. The universities may experience (1) an increase in costs for recruiting and replacement, (2) more time diverted to the hiring process, (3) a disruption of lectures and teaching programs, (4) a loss of research productivity, (5) discontinuation of student mentoring and supervision, and (6) diminished morale among those lecturers who remain in the institution (Ehrenberg, Kasper, \& Rees, 1990; Lew, 2011; Mobley, 1982; Price, 1977; Rosser, 2004; Xu, 2008). Hence, it is important to further examine the factors 
associated with lecturers' turnover, especially turnover intention is a good proxy of actual turnover (Choong et al., 2013; Daly \& Dee, 2006; Jackofsky, 1984; Lee \& Mitchell, 1994; Mobley, 1977; Mobley, Horner, \& Hollingsworth, 1978). The purpose of this study is to examine the factors that are associated with turnover intention among the lecturers.

Most of the studies have examined the significance of internal factors within the organization with turnover intention. These internal factors include various job facets such as the work itself, employee productivity, achievement motivation, co-workers' relationship, supervision, pay, working conditions, company policies and procedures, opportunity for promotion, organizational procedures and perceptions of control process, work roles and working hours (Mobley, Griffeth, Hand, \& Meglino, 1979; Oshagbemi, 2003; Yan, Yue, \& Niu, 2015). However, studies have overlooked the impact of internal factors such as role stress factors that may push lecturers to have intention to leave (Idris, 2010, 2011; Panatik, Rajab, Shaari, Mad Shah, Abdul Rahman \& Zainal Badri, 2012; Rageb, El-Samadicy, \& Farid, 2013). Furthermore, external pull factors outside the organization such as the availability of attractive alternatives have been largely overlooked to further understand employees' turnover intention (Matier, 1990; Mobley et al., 1979; Moore \& Gardner, 1992; Price, 2001; Xu, 2008; Yan et al., 2015; Zhou \& Volkwein, 2004). Finally, the review of literature has highlighted the importance of examining the relationships of both internal push factors and external pull factors on lecturers' turnover intention within the higher education sector (Ali Shah, Fakhr, Ahmad, \& Zaman, 2010; Daly \& Dee, 2006; Matier, 1990; Moore \& Gardner, 1992; Xu, 2008; Yan et al., 2015; Zhou \& Volkwein, 2004).

Various studies have revealed that employees who experience role stress may have a higher turnover intention (Ali Shah et al., 2010; Daly \& Dee, 2006; Netemeyer, Johnston, \& Burton, 1990; Ngo, Foley, \& Loi, 2005; Panatik et al., 2012; Rageb et al., 2013; Rizzo, House, \& Lirtzman, 1970). Role overload, role ambiguity and role conflict are classified as role stress factors, and these role stress factors are prevalent within the education sector (Ali Shah et al., 2010; Conley \& Woosley, 2000; Idris, 2011; Sutton, 1984). Sutton (1984) further mentioned that "role demands may become stressful to a teacher when expectations about a teacher's behaviour are not clear (role ambiguity), when they are excessive (role overload), or when meeting one set of expectations make meeting other expectations more difficult (role conflict)" (p. 9).

In this study, role stress factors are classified as internal push factors in examining their impacts on lecturers' turnover intention. Lecturers working in a highly stressful work place may have intention to quit (Ali Shah et al., 2010; Rajarajeswari, 2010). They may face role conflict when they have to bend a rule or policy of the university management, or when they receive conflicting requests from different parties (Idris, 2011). Additionally, lecturers may experience role ambiguity when there is a lack of clarity on how to juggle the different academic activities such as teaching, academic administration and research (Idris, 2011). Lastly, lecturers have insufficient time to keep abreast with the current developments in their fields. They are overloaded with various job demands within the time constrains (Daly \& Dee, 2006). As such, these role stressors may push employees to think about leaving the organization (Hassan, 2014; Idris, 2011; Rageb et al., 2013).

Past literature has also indicated that attractive external environmental factors may induce turnover intention (Abdul Aziz \& Ramli, 2010; Ali Shah et al., 2010; Matier, 1990; Mobley et al., 1979; Moore \& Gardner, 1992; Price, 2001; Semmer, Elfering, Bailord, Berset, \& Beehr, 2014). The four factors included as attractive external pull factors in this study are job opportunity, compensation, working location and university image (Ahmad \& Riaz, 2011; Ali Shah et al., 2010; Mahony, Mondello, Hums, \& Judd, 2006; Ryan, Healy, \& Sullivan, 2012; Yan et al., 2015; Zhou \& Volkwein, 2004). The review of past literature has highlighted that these four factors have been commonly cited as external pull factors, however relatively few studies have empirically tested these four factors with turnover intention. Hence in this study, these four external pull factors will be examined to study its effect on lecturers' turnover intention.

Lecturers may be attracted to external factors which could pull them to leave (Mobley et al., 1979; Xu, 2008; Yan et al., 2015; Zhou \& Volkwein, 2004). The availability of job opportunity will continue to attract employees as employees may perceive that they can better address their needs in another organisation (Ahmad \& Riaz, 2011; Dardar, Jusoh, \& Hasli, 2012). Furthermore, lecturers may perceive inequity in their compensation received when comparisons are made between their current university with other universities that provide better compensation packages (Govindasamy \& Jayasingam, 2010; Owence, Pinagase, \& Mercy, 2014; Rahimi, Hashim, Tahsidari, \& Khodakarami, 2013; Zakaria, Jidi, Zani, Mislan, \& Eshak, 2014). Additionally, lecturers may also be attracted to the prestigious universities as they aim for greater prestige and higher status in their academic career (Matier, 1990; O'Meara, 2014). Finally, an attractive location of a university (region/city) has a critical effect on mobility of lecturers as lecturers may be attracted to universities based on its regional/city advantages (Yan et al., 2015). 
Studies investigating the impacts of the internal push factors such as role stress factors and the attraction to external environmental pull factors on turnover intention are scant, especially in the higher education industry. To address this research gap, the present study aims to examine the relationships between these internal and external factors and lecturers' turnover intention.

\section{Literature Review and Hypotheses Development}

\subsection{Relationship between Role Overload and Turnover Intention}

According to Katz and Kahn (1978), role overload occurs when too much is expected of an individual with the time available or when demands exceed capabilities. Furthermore, Katz and Kahn (1978) stated that role overload might also occur when an individual received two or more expectations from role senders and the individual perceives the role expectations are too great to complete sufficiently or comfortably. Past literature have found that role overload has a positive significant relationship with turnover intention (Idris, 2010; Malik, Sajjad, Hyder Ahmad, Ahmed, \& Hussain, 2013; Ngo et al., 2005; Rageb et al., 2013).

Ngo et al.'s (2005) study on 887 professional clergies in Hong Kong found that role overload has a significant positive effect on turnover intention. These clergies were heavily involved in various work activities in the areas of administration, preaching and teaching. In the higher education sector, Rageb et al.'s (2013) study on 65 employees from the College of Management and Technology in Egypt found a significant positive relationship between role overload and turnover intention. Role overload, in comparison to other role stressors such as role ambiguity and role novelty, was found to have a much greater impact on lecturers' turnover intention. Similarly, Malik et al.'s (2013) study found that role overload had a strong negative significant relationship with employee retention and productivity. According to the authors, role overload accounted for about $85 \%$ variance in employee retention. As such, the hypothesis below was developed:

H1: Role overload has a positive relationship with turnover intention.

\subsection{Relationship between Role Ambiguity and Turnover Intention}

Role ambiguity occurs when the set of expected behaviours for a role is unclear due to the inexistence or lack of clarity on authority or knowledge that would allow individuals to perform the assigned jobs (Katz \& Kahn, 1978; Rizzo et al., 1970). Past studies on role ambiguity have often been associated to tension, low overall satisfaction, poor job performance, work exhaustion resulting to stress and turnover (Idris, 2010, 2011; Ngo et al., 2005).

Role ambiguity has a positive effect on intention to leave (Ali Shah et al., 2010; Idris, 2010; Ngo et al., 2005; Rai, 2015). Idris's (2010) research on 357 respondents from five big public teaching and research universities in Malaysia found that role ambiguity has a strong effect on strain, cynicism, organisational commitment and turnover intention. Similarly, Rai's (2015) study on work-related stress involving 511 long-term care staff from 10 different healthcare organisations in the United States found that role ambiguity significantly affected turnover intention. The author further mentioned that role stress among staff may be reduced if there is an open and accurate communication among staff through leader-member exchange. Hence, the following hypothesis was formulated:

H2: Role ambiguity has a positive relationship with turnover intention.

\subsection{Relationship between Role Conflict and Turnover Intention}

Kahn, Wolfe, Quinn, and Snoek (1964) stated that role conflict may occur when there are two or more sets of pressure occurring simultaneously and that the compliances with one would make it more difficult to comply with the other. Role conflict is defined as the degree of incongruity or incompatibility of expectations communicated to a particular role incumbent by his or her role sender (Katz \& Kahn, 1978).

According to past research, role conflict results in a higher turnover intention (Ali Shah et al., 2010; Daly \& Dee, 2006; Idris, 2010; Mowday, Porter, \& Steers, 1982; Netemeyer et al., 1990; Ngo et al., 2005; Rageb et al., 2013). Role conflict affects turnover intention as it pushes employees to leave their current workplace. Rageb et al.'s (2013) study found a significant positive relationship between role conflict and turnover intention among 65 employees from the College of Management and Technology. According to the authors, this may be due to the incongruence in employees' capabilities and job demands. Furthermore, Daly and Dee's (2006) study found a negative relationship between role conflict and intention to stay, based on a sample of 768 full-time instructional/research faculty staff study from 15 urban public universities in the United States. The authors suggested that role conflict could be reduced if university management clarifies the priorities and expectation of faculty work to their employees. As a result, the following hypothesis was developed:

H3: Role conflict is positively related to turnover intention. 


\subsection{Relationship between Job Opportunity and Turnover Intention}

Price (2001) defined job opportunity as "the availability of alternative jobs in environment and it is the type of labour market variable emphasized by economist" (p. 601). Hence, market opportunities would produce a greater awareness of alternative jobs in the environment to all employees (Price, 2001). Dardar et al. (2012) stated that external job opportunities may be more attractive when employees sense that alternative jobs can better address their needs. The exposure to attractive alternatives may lead to employees to re-evaluate their own jobs and develop an intention to quit (Ahmad \& Riaz, 2011; Dardar et al., 2012). Similarly, Price's (2001) study on the determinants of voluntary turnover proposed that employees' attraction to external job opportunities may lead to turnover intention.

A number of studies have found a positive relationship between more attractive job opportunity and turnover intention (Abdul Aziz \& Ramli, 2010; Ahmad \& Riaz, 2011; Price \& Mueller, 1986). Abdul Aziz and Ramli’s (2010) study on 128 lecturers found that employment opportunities contributed significantly to lecturers' intention to quit. Furthermore, Ahmad and Riaz's (2011) study involving 231 public-sector doctors from medical colleges and hospitals found that the more employment opportunities were available in the private sector, the stronger the employees' intention to leave their jobs. Consequently, the following hypothesis was developed:

H4: Lecturers who perceive a more attractive external job opportunity have a higher level of turnover intention.

\subsection{Relationship between External Compensation and Turnover Intention}

Mondy and Mondy (2014) defined compensation as the "total of all rewards provided to employees in return for their services for the purpose of attracting, retaining and motivating employees" (p. 248). Indeed, compensation is considered as one of the most important factors for attracting and retaining talent (Caplow \& McGee, 1958; Ghosh, Satyawadi, Joshi, \& Shadman, 2012; Irshad, 2011; Matier, 1990; Williams \& Dreher, 1992; Willis, 2000). Employees may compare their existing salary packages with those offered by other organizations. A lack of perceived fairness may occur when comparisons are made with similar but higher paying jobs outside of their organizations. These comparisons may lead to employees' feeling of inequity as they believe that they worth much more than what there are actually being paid (Govindasamy \& Jayasingam, 2010; Owence et al., 2014).

The most cited reason given by employees leaving their current workplace is the attraction and availability of higher paying jobs elsewhere (Mahony et al., 2006; Owence et al., 2014). Higher paid jobs with better employment benefits may pull employees away from their present employment. According to Ahmad, Toh, and Bujang (2013), most managers believe that employees are leaving to another company for better compensation. Finance is a means for them to satisfy their own sustenance, materialistic and recreational needs as well as ego and self-esteem needs. Lecturers' turnover intention would be affected if they perceive better pay benefits offered by counterpart organizations. Zhou and Volkwein (2004) did a national survey on 2,473 full-time faculty staff of research and doctoral institutions in the United States and found that attractive external job rewards had a significant direct effect on their intention to leave. As such, the hypothesis below was postulated:

H5: Lecturers who perceive a more attractive external compensation have a higher level of turnover intention.

\subsection{Relationship between External University Image and Turnover Intention}

University image is defined as the sum of all beliefs that an individual has towards the university (Duarte, Alves, \& Raposo, 2010). University image may be defined by the quality of teaching and research, quality of facilities, the reputation of the academic staff, and the reputation of a university. The reputation and perceived image of the university and the favorable information shared among professional groups play a significant role in attracting the best new scholars (Wenzel \& Hollenshead, 1998).

A lecturer who is a productive scholar and is well known for his/her work will attract interest from a more prestigious university (Ryan et al., 2012). Ali Shah et al.'s (2010) study on 100 teachers from five institutions of higher education in Pakistan revealed that a pull to join a reputable university affected lecturers' intention to quit. Similarly, Yan et al.'s (2015) study of 6,252 faculty members from 50 universities in China found that these academic staff felt enormous pressure to move to other prestigious universities due to a low recognition of own university's status and prestige. The prestige of a university plays a critical role in pulling faculty members away from their current positions. Hence, the following hypothesis was derived accordingly:

H6: Lecturers who perceive a more favorable image of other universities have a higher level of turnover intention.

\subsection{Relationship between External Working Location and Turnover Intention}

Kee (2011) defined working location as the geographical location of an organization. The attraction to a working 
location occurs when comparisons are made between home of stay and other universities in terms of accessibility of transportation, time taken commuting, distance, traffic, alternative commuting routes and also the parking facilities of other universities. Ingersoll (2011) found that the geographical location of a school plays an important role in teachers' turnover decision, whereby teachers in rural remote areas are more likely to leave as compared to teachers in urban metropolitan areas.

Holland and Arrington (1987) surveyed 463 staff of the Accounting Faculty who had relocated and found that geographical location was the primary factor in their job selection or relocation decisions. Mahony et al.'s (2006) study of 172 Sport Management lecturers indicated that external working location was an important consideration to those willing to take a new position in other universities. In addition, Yan et al.'s (2015) study found that external factors such as the region or city environment significantly predicted the faculty member's intention to leave. Region/city environment was an important factor in pulling faculty members away from their current university. The following hypothesis was formulated accordingly:

H7: Lecturers who perceive other working locations as more attractive will have a higher level of turnover intention.

Figure 1 below depicts the research model of the present study and the associated hypotheses.

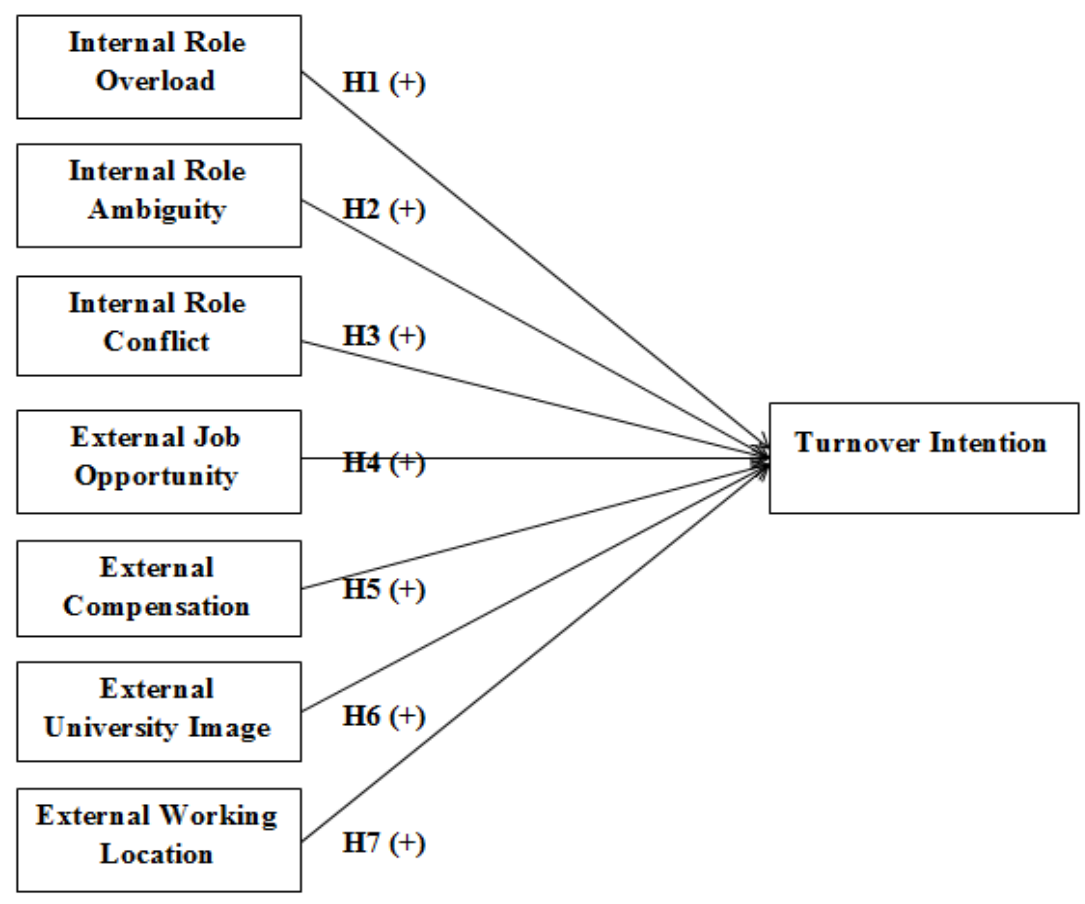

Figure 1. The research model

\section{Data and Result Analysis}

Self-administered questionnaires were used to collect data from 849 Business Faculty lecturers from 19 private universities situated in the education hub of the country. Business Faculty was chosen due to several reasons--the popularity of business programmes with its high student enrollment (MOHE, 2015), the expansion of programmes such as Islamic finance, banking and executive education in Malaysia (Tan, 2014), the increasing demand for business lecturers (Lee, 2004; Mckenna \& Sikula, 1981; Tan, 2014) and also the excessive workload and stress experience by business lecturers (Adrian, Cox, Phelps, Schuldt, \& Totten, 2014). The sample collected for this study amounted to 410 , with a response rate of $48.29 \%$. The sample size further reduced to 401 , with the exclusion of nine questionnaires due to extensive missing data.

The questionnaire comprised of two parts. The first part was designed to collect lecturers' demographic information. The second part of the questionnaire consisted of the measurement scales of the variables in study. 
The questionnaire utilized several measures. The scale for role overload was taken from Thiagarajan, Chakrabarty, and Taylor (2006). The authors conducted a confirmatory factor analysis and refined Reilly (1982) role overload scale from a 13 item scale to a six item scale. The scales for role ambiguity and role conflict were taken from Rizzo et al. (1970). The scale for job opportunity was taken from Daly and Dee (2006), the scale for compensation was adopted from Wood (1976), and those for university image were adopted from Duarte et al. (2010).

Due to the lack of an existing scale for working location, the present authors attempted to develop one using a focus group interview. The participants of this focus group consisted of 10 lecturers from a private university. They were informed of the purpose of the study and the definition of working location. They were instructed to think what was in the location of other universities would attract them in comparison to that of their own university. Based on their feedback, a six-item scale was generated to measure the attractiveness of other working locations. This scale covers several aspects of working location--accessibility of transportation, time taken commuting, distance, traffic, alternative commuting routes and parking facilities. Lastly, the scale for turnover intention was adopted from Mobley et al. (1978).

Each of the variables in study was measured using a 6-point Likert scale. The external pull factors; compensation, working location and university image were measured in terms of attractiveness ranging from $1=$ not attractive at all to $6=$ attractive to a very great extent. External pull factor; job opportunity, internal push factors and turnover intention were measured in terms of level of agreement ranging from $1=$ strongly disagree to $6=$ strongly agree. See Appendix for the items used to measure the variables included in this study.

\subsection{Demographics}

Majority of the respondents were female (60.8\%). The respondents varied widely in terms of race with $45.1 \%$ Malays, $23.9 \%$ Chinese and $22.7 \%$ Indians. In terms of age, $65.8 \%$ of the respondents were from the age group of 40 years and below. Majority (73.8\%) of them were married with a master's degree (70.8\%). About $66 \%$ of the respondents held the position title of Lecturer, while only $25.4 \%$ held the position of Senior Lecturer. The largest gross income group (41.9\%) was within the range of RM3,001 - RM5,000, followed by RM5,001RM7,000 (31.7\%). Majority (72.3\%) of the respondents were of permanent status employees. The average number of teaching years was five years, with a minimum of less than a year and a maximum of 22 years. The respondents' demographic profile is summarized in Table 1

Table 1. Demographic profile of respondents

\begin{tabular}{|c|c|c|c|}
\hline Demographic Features & & Frequency & Percentage \\
\hline \multirow[t]{2}{*}{ Gender } & Male & 155 & 38.7 \\
\hline & Female & 244 & 60.8 \\
\hline \multirow[t]{4}{*}{ Race } & Malay & 181 & 45.1 \\
\hline & Chinese & 96 & 23.9 \\
\hline & Indian & 91 & 22.7 \\
\hline & Others & 31 & 7.7 \\
\hline \multirow[t]{2}{*}{ Age } & 40 years and below & 264 & 65.8 \\
\hline & 41 years and above & 122 & 30.4 \\
\hline \multirow[t]{3}{*}{ Marital Status } & Single & 97 & 24.2 \\
\hline & Married & 296 & 73.8 \\
\hline & Others & 5 & 1.2 \\
\hline \multirow[t]{4}{*}{ Highest Education Qualification } & Professional Qualification & 13 & 3.2 \\
\hline & Bachelor's Degree & 14 & 3.5 \\
\hline & Master's Degree & 284 & 70.8 \\
\hline & Doctoral Degree & 87 & 21.7 \\
\hline \multirow[t]{5}{*}{ Academic Rank } & Lecturer & 263 & 65.6 \\
\hline & Senior Lecturer & 102 & 25.4 \\
\hline & Assistant Professor & 23 & 5.7 \\
\hline & Associate Professor & 6 & 1.5 \\
\hline & Professor & 5 & 1.2 \\
\hline \multirow[t]{3}{*}{ Gross Income } & Less than RM3 000 & 15 & 3.7 \\
\hline & RM3 001 - RM5 000 & 168 & 41.9 \\
\hline & RM5 001- RM7 000 & 127 & 31.7 \\
\hline
\end{tabular}




\begin{tabular}{|c|c|c|c|}
\hline & RM7 001-RM9 000 & 49 & 12.2 \\
\hline & RM9 001-RM11 000 & 23 & 5.7 \\
\hline & RM11 001-RM13000 & 8 & 2.0 \\
\hline \multirow{3}{*}{ Employment Status } & More than RM15 000 & 3 & .7 \\
\hline & Probation & 20 & 5.0 \\
\hline & Permanent & 290 & 72.3 \\
\hline \multirow{3}{*}{ Number of teaching years } & Contractual & 89 & 22.2 \\
\hline & Minimum: less than 1 year & 42 & 10.1 \\
\hline & Maximum: more than 22 years & 1 & 0.2 \\
\hline
\end{tabular}

\subsection{Exploratory Factor Analysis}

Exploratory factor analysis (EFA) is used to explore the factor structure of the underlying variables (Hair, Black, Babin, \& Anderson, 2013). EFA may be used when a new scale has been developed for a questionnaire (Hair, et al., 2013). Furthermore, EFA is an addition to the reliability test in determining whether items are within the same construct (Hair et al., 2013). EFA will determine the correlation among variables in the dataset and group variables based on strong correlations. As such, before analyzing data with confirmatory factor analysis (CFA), EFA was conducted in this study for external pull factors to identify the dimensionality of items and to drop items that have a low factor loading as well as redundant items (Awang, 2014; Hair et al., 2013). In this study, EFA was conducted to categorise the suitable items for each of the external pull factors using principal component analysis (PCA) and varimax rotation; these are two commonly used methods (Hair et al., 2013).

The Kaiser-Meyer-Olkin (KMO) scores for the external factors were as follows: 0.762 for job opportunity, 0.906 for compensation, 0.897 for university image and 0.906 for working location. All the KMO scores were above the required minimum threshold of greater than 0.7 (Hair et al., 2013). Bartlett's Test of Sphericity value for external pull factors was significant at $p<0.05$ and all external pull factors produced an eigenvalue of greater than 1 (Hair et al., 2013). Table 2 shows the factor loadings from the rotated component matrix conducted for external pull factors. Only items with factor loading of 0.5 and above are considered (Hair et al., 2013). The results show that compensation loaded as the first factor, working location as the second factor, university image as the third factor and job opportunity as the fourth factor. All the items used to measure each external pull factor were categorised into the respective factor accordingly.

Table 2. EFA factor loadings for external pull factors

\begin{tabular}{|c|c|c|c|c|}
\hline \multirow[t]{2}{*}{ Items } & \multicolumn{4}{|l|}{ Construct } \\
\hline & Compensation & $\begin{array}{l}\text { Working } \\
\text { Location }\end{array}$ & $\begin{array}{l}\text { University } \\
\text { Image }\end{array}$ & $\begin{array}{l}\text { Job } \\
\text { Opportunity }\end{array}$ \\
\hline $\begin{array}{l}\text { The pay increment paid to lecturers in other universities. } \\
\text { (Compensation) }\end{array}$ & .873 & & & \\
\hline $\begin{array}{l}\text { The amount of salary paid to lecturers in other universities. } \\
\text { Compensation) }\end{array}$ & .859 & & & \\
\hline The bonus paid to lecturers in other universities. (Compensation) & .853 & & & \\
\hline $\begin{array}{l}\text { The fringe benefits paid to lecturers in other universities. } \\
\text { (Compensation) }\end{array}$ & .846 & & & \\
\hline $\begin{array}{l}\text { The range of salaries paid to lecturers in other universities } \\
\text { (Compensation) }\end{array}$ & .845 & & & \\
\hline The incentives paid to lecturers in other universities (Compensation) & .833 & & & \\
\hline $\begin{array}{l}\text { The method used to determine salary in other universities } \\
\text { (Compensation) }\end{array}$ & .726 & & & \\
\hline $\begin{array}{l}\text { Distance between my place of stay and other universities. (Working } \\
\text { Location) }\end{array}$ & & .917 & & \\
\hline $\begin{array}{l}\text { Time taken commuting between my place of stay and other universities. } \\
\text { (Working Location) }\end{array}$ & & .903 & & \\
\hline $\begin{array}{l}\text { Traffic between my place of stay and other universities. (Working } \\
\text { Location) }\end{array}$ & & .897 & & \\
\hline Alternatives commuting routes between my place of stay and other & & .878 & & \\
\hline
\end{tabular}




\section{universities .(Working Location)}

Accessibility of transportation between my place of stay and other universities (Working Location)

.870

.608

\section{Location)}

The national academic reputation of other universities. (University Image)

Being a well-known university. (University Image)

The reputation of lecturers in other universities. (University Image)

(University Image)

The teaching quality in other universities.

(University Image)

There is at least one good academic job that i could begin immediately if

i were to leave my current university.(Job Opportunity)

.793

There are plenty of good academic jobs that i could have outside my current university. (Job Opportunity)

It would be difficult for me to find another academic job that i like as much as my current job at the university. (Job Opportunity)

\subsection{Confirmatory Factor Analysis}

Confirmatory factor analysis (CFA) is used to assess the unidimensionality, validity and reliability of the latent constructs (Awang, 2014). While EFA is used to explore the data and provide the researcher with information about how many factors are needed to best represent the data of this study, the CFA will be used to provide confirmatory test of the measurement model (Hair et al., 2013). The CFA of a measuring instrument is most appropriately applied to measures that are fully developed and their factor structures validated (Byrne, 2010). Hence, CFA is conducted for the factor validity of the theoretical constructs of internal push factors, external pull factors and turnover intention.

In order to confirm the unidimensionality, validity and reliability of all latent constructs involved in this study before modelling the interrelationships in SEM, CFA will be conducted to remove any item that does not fit in the measurement model (Awang, 2014; Biswakarma, 2016; Hair et al., 2013). Items with a low factor loading, i.e., less than 0.60, will be deleted from the measurement model (Awang, 2014; Biswakarma, 2016; Byrne, 2010; Hair et al., 2013).Based on the result of the CFA, two of the five items measuring job opportunity were deleted. They were (1) "given the state of the academic job market, finding a job would be very difficult for me," and (2) "it would be difficult for me to find another academic job that I like as much as my current job at the university". Similarly, one of the eight items measuring role conflict was deleted. The item was "I have to do things that should be done differently."

After examining the fit of measurement model, the next step is to examine the fit of the structural model of the data. Three types of fit were examined in this study - the parsimonious fit, the absolute fit and the incremental fit The parsimonious fit was measured using normed chi-square $\left(\chi^{2} / d f\right)$ to determine the model fit in comparison to models of different complexity (Hair et al., 2013). The normed chi square ratio (CMIN/df) should be in the range of 1 to 5 for a sample size of more than 200 (Hair et al., 2013). The absolute fit was examined using goodness of fit index (GFI) and root mean square error of approximation (RMSEA) (Hair et al., 2013). The absolute fit measures how well the model specified by the researcher reproduces the observe data. The GFI value should be more than 0.80 while the RMSEA index must be less than 0.80 (Byrne, 2010;=Hair et al., 2013). Lastly, the incremental fit examines how fit the estimated model is with relative to some alternative baseline model using the Tucker-Lewis Index (TLI) and Comparative Fit Index (CFI) (Hair et al., 2013). TLI should be above 0.90 while CFI should be above 0.95 (Hair et al., 2013).

The results of the fit analysis showed that $\mathrm{CMIN} / \mathrm{df}$ (ratio) $=2.090$, which was within the recommended range of 
1 to $5 . \mathrm{GFI}=0.832$ was permissible at GFI $>0.80$, and RMSEA $=0.052$ showed a fair fit as it was less than 0.80 . $\mathrm{TLI}=0.934$ and CFI $=0.941$ were within the threshold of greater than 0.90 and 0.95 respectively. In sum, the results showed that the structural model of this study has achieved a reasonably good fit.

\subsection{Reliability and Validity Test}

According to Hair et al. (2013), the acceptable internal reliability of Cronbach's alpha value is 0.70 and above. All the eight constructs in this study achieved a good internal reliability with Cronbach's alpha of greater than 0.90 . As for the composite reliability (CR), all constructs in this study achieved a CR value of $\geq 0.90$, which is above the required value of $\geq 0.70$ (Hair et al., 2013). Convergent validity of the data was assessed using the average variance extracted (AVE) value, which must be greater than 0.5 for each construct (Hair et al., 2013). In this study, all of the constructs produced AVEs of above 0.50, indicating that all variables have achieved convergent validity. With regards to discriminant validity, the rule of thumb is that the AVE for each construct must be more than the maximum shared squared variance (MSV) and average shared squared variance (ASV) respectively (Hair et al., 2013). All six constructs produced AVE values that are more than the MSV and ASV values; hence, discriminant validity of the data was achieved. Table 3 shows the reliability and validity of each construct.

Table 3. Reliability and validity of constructs

\begin{tabular}{|c|c|c|c|c|c|c|c|}
\hline Construct & Items & $\begin{array}{l}\text { Factor } \\
\text { Loading }\end{array}$ & Cronbach Alpha & $\mathbf{C R}$ & AVE & MSV & ASV \\
\hline \multirow[t]{6}{*}{ Role Overload } & A1 & 0.779 & 0.912 & 0.908 & 0.623 & 0.518 & 0.125 \\
\hline & A2 & 0.807 & & & & & \\
\hline & $\mathrm{A} 3$ & 0.840 & & & & & \\
\hline & A4 & 0.865 & & & & & \\
\hline & A5 & 0.710 & & & & & \\
\hline & A6 & 0.723 & & & & & \\
\hline \multirow[t]{6}{*}{ Role Ambiguity } & $\mathrm{B} 1$ & 0.758 & 0.917 & 0.917 & 0.650 & 0.147 & 0.047 \\
\hline & B2 & 0.804 & & & & & \\
\hline & B3 & 0.860 & & & & & \\
\hline & B4 & 0.775 & & & & & \\
\hline & B5 & 0.867 & & & & & \\
\hline & B6 & 0.767 & & & & & \\
\hline \multirow[t]{7}{*}{ Role Conflict } & $\mathrm{C} 2$ & 0.760 & 0.910 & 0.916 & 0.610 & 0.518 & 0.144 \\
\hline & $\mathrm{C} 3$ & 0.830 & & & & & \\
\hline & $\mathrm{C} 4$ & 0.831 & & & & & \\
\hline & $\mathrm{C} 5$ & 0.764 & & & & & \\
\hline & $\mathrm{C} 6$ & 0.791 & & & & & \\
\hline & $\mathrm{C} 7$ & 0.791 & & & & & \\
\hline & $\mathrm{C} 8$ & 0.693 & & & & & \\
\hline \multirow[t]{3}{*}{ Job Opportunity } & D1 & 0.651 & 0.827 & 0.835 & 0.632 & 0.101 & 0.034 \\
\hline & D4 & 0.812 & & & & & \\
\hline & D5 & 0.901 & & & & & \\
\hline \multirow[t]{7}{*}{ Compensation } & K1 & 0.735 & 0.956 & 0.952 & 0.742 & 0.346 & 0.103 \\
\hline & $\mathrm{K} 2$ & 0.813 & & & & & \\
\hline & K3 & 0.877 & & & & & \\
\hline & K4 & 0.895 & & & & & \\
\hline & K5 & 0.898 & & & & & \\
\hline & K6 & 0.910 & & & & & \\
\hline & K7 & 0.887 & & & & & \\
\hline \multirow[t]{5}{*}{ University Image } & L1 & 0.620 & 0.924 & 0.923 & 0.671 & 0.346 & 0.102 \\
\hline & L2 & 0.752 & & & & & \\
\hline & L3 & 0.875 & & & & & \\
\hline & L4 & 0.895 & & & & & \\
\hline & L5 & 0.917 & & & & & \\
\hline
\end{tabular}




\begin{tabular}{|c|c|c|c|c|c|c|c|}
\hline & L6 & 0.816 & & & & & \\
\hline \multirow[t]{6}{*}{ Working Location } & M1 & 0.864 & 0.939 & 0.943 & 0.746 & 0.188 & 0.054 \\
\hline & M2 & 0.915 & & & & & \\
\hline & M3 & 0.934 & & & & & \\
\hline & M4 & 0901 & & & & & \\
\hline & M5 & 0.885 & & & & & \\
\hline & M6 & 0.604 & & & & & \\
\hline \multirow[t]{3}{*}{ Turnover intention } & $\mathrm{O} 1$ & 0.908 & 0.943 & 0.944 & 0.848 & 0.192 & 0.071 \\
\hline & $\mathrm{O} 2$ & 0.931 & & & & & \\
\hline & $\mathrm{O} 3$ & 0.924 & & & & & \\
\hline
\end{tabular}

\subsection{Results}

Table 4 presents the standardized regression weights of the SEM analysis. The results show that $\mathrm{H} 1(\beta=0.187$; $p=0.002), H 2(\beta=0.130 ; p=0.008), H 3(\beta=0.203 ; p=0.001)$, and $\mathrm{H} 7(\beta=0.104 ; p=0.046)$ were supported by the data. This study found that role overload, role ambiguity, role conflict (the three internal push factors) and working location (an external pull factor) were significant predictors of lecturers' turnover intention.

Table 4. Standardized regression weights

\begin{tabular}{llllllll}
\hline & Path & & & Standardized Estimate & S.E. & C.R. & P \\
\hline H1 & Turnover Intention & $<---$ & Role Overload & .187 & .079 & 3.103 & .002 \\
H2 & Turnover Intention & $<---$ & Role Ambiguity & .130 & .075 & 2.647 & .008 \\
H3 & Turnover Intention & $<---$ & Role Conflict & .203 & .083 & 3.200 & .001 \\
H4 & Turnover Intention & $<---$ & Job Opportunity & -.072 & .072 & -1.509 & .131 \\
H5 & Turnover Intention & $<---$ & Compensation & .058 & .078 & .977 & .329 \\
H6 & Turnover Intention & $<---$ & University Image & .001 & .087 & .018 & .986 \\
H7 & Turnover Intention & $<---$ & Working location & .104 & .064 & 1.997 & .046 \\
\hline
\end{tabular}

\section{Discussion and Conclusion}

The study was undertaken to examine the relationships between both internal push factors and external pull factors and lecturers' turnover intention. The research findings show that turnover intention is affected by internal role overload, role ambiguity, role conflict and external working location. As per previous research, role conflict was found to have a positive and significant relationship with lecturers' turnover intention (Ali Shah et al., 2010; Daly \& Dee, 2006; Idris, 2010; Mowday et al., 1982; Netemeyer et al., 1990; Ngo et al., 2005; Rageb et al., 2013; Rizzo et al., 1970).

More attention should be given to lecturers' well being given the strategic roles of universities in the education industry. Through the development of the institutes of higher education, the country aims to build a research, knowledge-based economy. In concordance with this, a lecturer's role has evolved to include not only teaching and academic administration but also research and development. Lecturers may experience conflict between the various roles that they need to take up at their workplace. Lecturers are teachers, researchers, administrators, advisors, consultants, trainers, supervisors, faculty representatives and managers. They should be given sufficient time, resources and emotional support to fulfill their respective roles to reduce role conflict. Strategies to reduce lecturers' role conflict include increased communication, granting some degree of autonomy, providing training in time management and avoiding clashing of faculty work deadlines (Olsen, 1992).

In consistent with the findings of previous studies, role overload was also found to have a positive, significant relationship with lecturers' turnover intention (Abdul Aziz \& Ramli, 2010; Idris, 2010; Malik et al., 2013; Rageb et al., 2013). Lecturers' role demands may have increased with changes in technologies and policies, increased lecturers' workload, increase in student population and student diversity. Furthermore, job demands may have also increased due to the need to deal with a large number of students and excessive administrative work. Lecturers may feel compelled to stay back at work after normal working hours, or to bring home their work just to complete their workload in time. Some strategies to reduce lecturers' role overload include employing tutors 
to reduce the teaching workload, employing research assistants to assist lecturers in their research, engaging them less in paperwork and reducing the number of teaching hours. In addition, a relatively small student-to-lecturer ratio may indirectly reduce the workload of a lecturer when managing his/her classes (Bowen \& Schuster, 1986). Finally, lecturers should also be consulted first if they agree to take on additional roles.

Similar to the studies of Ali Shah et al. (2010), Idris (2010), Ngo et al. (2005) and Rai (2015), role ambiguity is another factor that contributes significantly to lecturers' turnover intention. Private universities are facing a complex environment in fulfilling the requirements of various stakeholders. This may have led to an increase in demand with respect to the roles assumed by the lecturers. Lecturers may face role ambiguity when there is a lack of clarity on how to juggle the different academic activities of teaching, administration and research (Idris, 2011). As such, lecturers may be uncertain about the key requirements of their job position and how they are expected to perform their job roles. Lecturers may not be receiving the necessary feedback from their respective faculties on the performance of each of their roles. Hence, university management must make it clear to the lecturers with regards to the demands required by their respective roles. Policy makers, the education ministry, and university management should work on a common framework that clearly defines the roles, duties, responsibilities and rights of a lecturer. They can also provide specific job descriptions and procedures with expected outcomes and evaluation criteria.

Furthermore, Idris (2011) proposed that role ambiguity can be reduced through (1) job briefing--whereby lecturers are briefed about their roles and responsibilities so that they are well informed of the job demands; (2) training--for career growth and development; (3) skill variety--allow opportunity for lecturers to learn the necessary skills in performing different roles; (4) task identity-- allow lecturers to successfully complete their tasks from the beginning to the end, (5) job autonomy--allow lecturers to have the freedom to make job-related decisions; and (6) constructive feedback--to improve teaching style and quality of research among the lecturers.

Lastly, only one external pull factor, namely working location, found to be a significant predictor of lecturers' turnover intention. Studies found to have a similar finding include Holland and Arrington (1987), Mahony et al. (2006), and Yan et al. (2015). The urbanization of the capital city and its surrounding areas has increased the traffic congestion abruptly and the time commuting to the workplace. As such, universities could look into improving transportation and traffic congestion at their respective locations, plus improving the parking facilities by working closely with respective local town and municipal councils. The construction of additional Mass Rapid Transit (MRT) lines may be able to reduce the time needed to commute between the place of stay and work. An MRT station located at the vicinity of the university may make the university more attractive to lecturers. Housing facilities may also be provided by the university to reduce the time commuting from one place to the other.

This study does have several limitations. Firstly, only lecturers from the business faculty of private universities were included in the study. Secondly, the study did not include personal factors in examining lecturers' turnover intention. Nevertheless, this study has highlighted the dynamic effects of both internal push factors and external pull factors on lecturers' turnover intention. Future studies should include a broader based population of lecturers from the public and foreign universities to allow for a comparative study. The examination of the lecturers from other faculties may be warranted as they may have different needs and expectations. Future research examining lecturers' turnover intention may include personal factors (e.g., family background) and other internal push factors (e.g., working and student relationships) and external pull factors (e.g., career advancement opportunity available in other organizations). Also, it would be interesting to see whether there is a changing effect over time by conducting a longitudinal study - to determine whether there is an increased importance of external factors in explaining employee turnover.

In conclusion, the findings of this study have contributed to the existing literature on the understanding of both push and pull factors in relation to academic staff's turnover intention (Daly \& Dee, 2006; Matier, 1990; Xu, 2008; Yan et al., 2015; Zhou \& Volkwein, 2004). Internal role stressors seem to play a much more significant role than external pull factors on lecturers' turnover intention. In order to retain caliber academic staff, improvement should be made on the job aspects to attract and retain academic staff. The results from this study carry an important message to various parties - the policy makers, the government, the association of institutes of higher education, the recruitment bodies, the university governance and educators--that policies and practices have to be installed and implemented in a synchronized way to reduce lecturer turnover. Lecturers are the intellectual resources of the university and they serve as a strategic weapon in this increasingly competitive and globalised economy. 


\section{References}

Abdul Aziz, N. N., \& Ramli, H. (2010). Determining critical success factors of intention to quit among lecturers: An empirical evidence study at UiTM Jengka. Gading Business and Management Journal, 14, 33-45.

Abdullah Hashim, R., \& Mahmood, R. (2011). What is the state of job satisfaction among academic staff at Malaysian Universities? University Tun Abdul Razak, E-Journal, 7(1), 15-25.

Adrian, C. M., Cox, S. S., Phelps, L. D., Schuldt, B. A., \& Totten, J. W. (2014). Issues causing stress among business faculty members. Journal of Academic Administration in Higher Education, 10(1), 41-46.

Ahmad, R., Toh, E. P. Y., \& Bujang, S. (2013). Relationship between types of benefit (leave, loan and retirement plan) and employees retention. International Journal of Education and Research, 1(8), 1-13.

Ahmad, T., \& Riaz, A. (2011). Factors affecting turnover intentions of doctors in public sector medical colleges and hospitals. Interdisciplinary Journal of Research in Business, 1(10), 57-66.

Ali Shah, I., Fakhr, Z., Ahmad, M. S., \& Zaman, K. (2010). Measuring push \& pull factors affecting turnover intentions: A case of university teachers in Pakistan. Review of Economic \& Business Studies, 3(1), June, 167-192.

Amin, M. (2002). Tinjauan terhadap budaya pengurusan organisasi dan hubungan dengan hasilan perlakuan: Satu kajian kes di L\&G. Master of Science thesis, Twintech Institute of Technology, Selangor.

Arokiasamy, L., Ismail, M., Ahmad, A., \& Othman, J. (2011). Predictors of academics career advancement at Malaysian private universities. Journal of European Industrial Training, 35(6), 591-605. http://dx.doi.org/10.1108/03090591111150112

Awang, Z. (2014). A Handbook on SEM (Structural Equation Modeling), Using AMOS Graphic. Kota Bharu: Universiti Teknologi Mara Kelantan.

Biswakarma, G. (2016). Organisational career growth and employees' turnover intentions. An empirical evidence from Napalese privae commercial banks. International Academic Journal of Organisational Behaviour and Human Resource Management, 3(2), 10-26.

Bowen, H. R., \& Schuster, J. H. (1986). American Professors: A national resource imperiled (1st ed.). New York: Oxford University Press.

Byrne, B. M. (2010). Structural Equation Modeling with AMOS (2nd ed.). New York: Routledge.

Caplow, T., \& McGee, R. J. (1958). The Academic Marketplace. New York: Basic Books.

Ch'ng, H. K., Chong, W. K., \& Nakaesvari. (2010). The satisfaction level of Penang private colleges lecturers. International Journal of Trade, Economics and Finance, 1(2), 168-172. http://dx.doi.org/10.7763/IJTEF.2010.V1.30

Choong, Y. O., Keh, C., G., Tan, Y. T., \& Tan, C. E. (2013). Impacts of demographic antecedent toward turnover intention amongst academic staff in Malaysian Private Universities. Australian Journal of Basic and Applied Sciences, 7(6), 46-54.

Conley, S., \& Woosley, S. A.(2000).Teacher role stress, higher order needs and work outcomes. Journal of Education and Administration, 38(2), 179-201. http://dx.doi.org/10.1108/09578230010320163

Coverman, S. (1989). Role overload, role conflict, and stress: Addressing consequences of multiple role demands. Social Forces, 67, 965-982. http://dx.doi.org/10.1093/sf/67.4.965

Daly, C. J., \& Dee, J. R. (2006). Greener pastures: Faculty turnover intention in urban public universities. The Journal of Higher Education, 77(5), 776-803. http://dx.doi.org/10.1353/jhe.2006.0040

Dardar, A. H. A., Jusoh, A., \& Rosli, A. (2012). The impact of job training, job satisfaction and alternative job opportunities on job turnover in Libyan oil companies: The 2012 International Conference on Asia Pacific business Innovation \& Technology Management. Social Science Behaviour 40, $389-394$. http://dx.doi.org/10.1016/j.sbspro.2012.03.205

Duarte, P. O. Alves, H. B., \& Raposo, M. B. (2010). Understanding university image: A structural equation model approach. International Rev Public Nonprofit Mark 7, 21-36. http://dx.doi.org/10.1007/s12208-009-0042-9

Ehrenberg, R., Kasper, H., \& Rees, D. (1990). Faculty turnover at American colleges and universities: Analysis of AAUP data. Paper presented at the American Economic Association annual meeting, Atlanta, GA, 
December 1989.

Ghosh, P., Satyawadi, R., Joshi, J. P., \& Shadman, M. (2012). Who stays with you? Factors predicting employees' intention to stay. International Journal of Organisational Analysis, 21(3), 288-312 http://dx.doi.org/10.1108/IJOA-Sep-2011-0511

Govindasamy, M., \& Jayasingam, S. (2010). A study on factors affecting affective commitment among knowledge workers in Malaysia. In Knowledge Management International Conference 2010 (KMICE2020), 25-27 May 2010, Kuala Terengganu, Malaysia.

Hair, J. F., Black, W. C., Babin, B. J., \& Anderson, R. E. (2013). Multivariate Data Analysis (17th ed.). New Delhi: India. Pearson.

Hassan, R. (2014). Factors influencing turnover intention among technical employees in information technology organization: a case of XYZ (M) SDN BHD. International Journal of Arts and Commerce, 3(9), 120-137.

Holland, R. G., \& Arrington, C. E. (1987). Issues influencing the decision of accounting faculty to relocate. Issues in Accounting Education Review, 57-71.

Idris, M. K. (2010). Strain in teaching and research: Structural equation modeling approach. International Journal of Economics and Management, 4(1), 137-154.

Idris, M. K. (2011). Over time effects of role stress on psychological strain among Malaysian Public University Academics. International Journal of Business and Social Sciences, 2(9), 154-161.

Ingersoll, R. M. (2001). Teacher turnover and teacher shortage: An organizational analysis. American Educational Research Journal, 38, 499-534. http://dx.doi.org/10.3102/00028312038003499

Irshad, M. (2011). Factors affecting employee retention. Evidence from literature review. Abasyn University Journal of Social Sciences, 4(1), 84-102.

Jackofsky, E. F. (1984). Turnover and job performance: An integrated process model. Academy of Management Review, 9, 74-83.

Kahn, R., Wolfe, D., Quinn, R., \& Snoek, D. (1964). Organizational stress: Studies in role conflict and ambiguity. New York: John Wiley.

Katz, D., \& Kahn, R. L. (1978). The Social psychology of Organizations (2nd ed.). New York: John Wiley \& Sons.

Kee, J. M. S. (2011). Post-Secondary student behaviour in the college choice decision. Journal of Marketing Research \& Case Studies. http://dx.doi.org/10.5171/2011.440964

Lee, M. M. N. (2004). Malaysian Teacher Education in to the new century, reform of teacher education in the Asia-Pacific in the new millennium. Education in the Asia-Pacific Region: Issues Concerns and Prospects, 3, 81-91.

Lee, T. W., \& Mitchell, R. R. (1994). An alternative approach: The unfolding model of employee turnover. Academy of Management Review, 19, 51-89. http://dx.doi.org/10.1007/978-1-4020-2722-2_6

Lew, T. K. (2011). Understanding the antecedents of affective organizational commitment and turnover intention of academics in Malaysia: The organisational support theory perspectives. African Journal of Business Management, 5(7), 2551-2562. http://dx.doi.org/10.5897/AJBM10.284

Mahony, D. F., Mondello, M., Hums, M. A., \& Judd, M. (2006). Recruiting and Retaining sport management faculty: Factors affecting job choice. Journal of Sport Management, 20, 414-430. http://dx.doi.org/10.1123/jsm.20.3.414

Malik, M. I., Sajjad, M., Hyder, S., Ahmad, M. S., Ahmed, J., \& Hussain, S. (2013). Role overload: A cause of diminishing employee retention and productivity. Middle-East Journal of Scientific Research, 18(11), 1573-1577.

March, J. G., \& Simon, H. A. (1958). Organisations. New York: Wiley.

Matier, M. W. (1990). Retaining faculty: A tale of two campuses. Research in Higher Education 31(1), 39-60. http://dx.doi.org/10.1007/BF00992556

McKenna, J. F., \& Sikula, A. F. (1981). On the move through the groves of academe: Mobility among business professors. Business Horizons, 24, 70-75. http://dx.doi.org/10.1016/0007-6813(81)90029-X

Ministry of Higher Education. (2013). National Higher Education Statistics. Retrieved from 
http://www.mohe.gov.my

Ministry of Higher Education. (2015). National Higher Education Report. Retrieved from http://www.mohe.gov.my

Mobley, W. H. (1977). Intermediate linkages in the relationship between job satisfaction and employee turnover. Journal of Applied Psychology, 62(2), 237-240. http://dx.doi.org/10.1037/0021-9010.62.2.237

Mobley, W. H. (1982). Employee Turnover: Causes, Consequences, and Control. Philippines: Addison-Wesley.

Mobley, W. H., Griffeth, R. W., Hand, H., \& Meglino, B. (1979). Review and conceptual analysis of the employee turnover process. Psychological Bulletin, 86(3), 493-522. http://dx.doi.org/10.1037/0033-2909.86.3.493

Mobley, W. H., Horner, S. O., \& Hollingsworth, A. T. (1978). An evaluation of precursors of hospital employee turnover. Journal of Applied Psychology, 63(4), 408-414. http://dx.doi.org/10.1037/0021-9010.63.4.408

Mondy, R. W., \& Mondy, J. B. (2014). Human Resource Management (13th ed.). England: Pearson.

Moore, K. M., \& Gardner, P. D. (1992). Faculty in a time of change: Job Satisfaction and career mobility. East Lansing: Michigan State University.

Morrison, E., Rudd, E., Picciano, J., \& Nerad, M. (2011). Are you satisfied? PhD education and faculty taste for prestige: Limits of the prestige value system. Research Higher Education, 52, 24-26. http://dx.doi.org/10.1007/s11162-010-9184-1

Mowday, R. T, Porter, L., W., \& Steers, R. M. (1982). Employee organisation linkages: The Psychology of commitment, absenteeism and turnover. New York: Academic Press.

Netemeyer, R. G., Johnston, M. W., \& Burton, S. (1990). Analysis of role conflicts and role ambiguity in a structural equations framework. Journal of Applied Psychology, 75(2), 148-157. http://dx.doi.org/10.1037/0021-9010.75.2.148

Ngo, H. Y., Foley, S., \& Loi, R. (2005). Work role stressors and turnover intentions: A study of professional clergy in Hong Kong. International Journal of Human Resource Management, 16(11), 213-2146. http://dx.doi.org/10.1080/09585190500315141

O’Meara, K. (2014). Half-way out: How requiring outside offers to raise salaries influences faculty retention and organizational commitment. Research in Higher Education, 55(4), 1-22.

Olsen, D. (1992). Interviews with existing faculty: Why do they leave? Improve Academy, 11, 35-47.

Oshagbemi, T. (2003). Personal correlates of job satisfaction: Empirical evidence from UK Universities. $\begin{array}{lllll}\text { International Journal of Social Economics, } & 30(12), & 1210-1232 .\end{array}$ http://dx.doi.org/10.5901/mjss.2014.v5n11p69

Owence, C., Pinagase, T. G., \& Mercy, M. M. (2014). Causes and effects of staff turnover in the academic development centre: A case of historically black university in South Africa. Mediterranean Journal of Social Sciences, 5(11), 69-76. http://dx.doi.org/10.5901/mjss.2014.v5n11p69

Panatik, S. A., Rajab, A., Shaari, R., Mad Shah, I., Abdul Rahman, H., \& Zainal Badri, S. K. (2012). Impact of Work-related stress on well-being among academician in Malaysian research University. International Conference on Education and Management Innovation, 30, 37-41.

Price, J. L. (1977). The study of turnover (1st ed.). IA: Iowa State University Press.

Price, J. L. (2001). Reflections on the determinants of voluntary turnover. International Journal of Manpower, 22(7), 600-624. http://dx.doi.org/10.1108/EUM0000000006233

Price, J. L., \& Mueller, C. W. (1986). Absenteeism and turnover in hospital employees. Greenwich, CT: JAL.

Rageb, M. A., Abd-El-Salam, E. M., El-Samadicy, A., \& Farid, S. (2013). Organisational commitment, job satisfaction and job performance as a mediator between role stressors and turnover intention. A study from an Egyptian cultural perspective. The Business \& Management Review, 3(2), 51-73.

Rahimi, M., Hashim, M. T., Tahsidari, H., \& Khodakarami, P. (2013). The relationship between perceptions of equity and job satisfaction among employees of Malaysian universities. International Journal of Iinnovation and Business Strategy, 2, 59-72.

Rai, G. S. (2015). Turnover intentions among long-term care staff: Three possible culprits. International Journal of Business and Social Science, 6(8), 1-9. 
Rajarajeswari, S. (2010). Role stress among the aided and self-financing college teachers: A discriminant analysis. Global Management Review, 4(4), 73-86.

Reilly, M. D. (1982). Working wives and convenience consumption. Journal of Consumer Research, 10, 407-418. http://dx.doi.org/10.1086/208881

Rizzo, J. R., House, R. J., \& Lirtzman, S. I. (1970). Role conflict and ambiguity in complex organizations. Administrative Science Quarterly, 15, 150-163. http://dx.doi.org/10.2307/2391486

Rosser, V. J. (2004). Faculty members' intention to leave: A national study on their work life and satisfaction. Research in Higher Education, 45, 285-309. http://dx.doi.org/10.1007/s 11162-004-6290-y

Ryan, J. F., Healy, R., \& Sullivan, J. (2012). Oh won't you stay. Predictors of faculty intent to leave a public research university. Higher Education, 63, 421-437. http://dx.doi.org/ 10.1007/s10734-011-9448-5

Semmer, N. K., Elfering, A., Baillod, J., Berset, M., \& Beehr, T. (2014). Push and pull motivations for quitting: A three-wave investigation of predictors and consequences of turnover. Zeitschrift für Arbeits-und Organisations Psychologie, 58(4), 173-185. http://dx.doi.org/10.1026/0932-4089/a000167

Sutton, R. I. (1984). Job stress among primary and secondary schoolteachers: Its relationship to ill-being. Work and Occupations, 11(1) 7-28. http://dx.doi.org/10.1177/0730888484011001002

Tan, C. (2014). Malaysian Business schools well-poised for regional growth. Retrieved from http://epaper.segi.edu.my/Sections/EduNews/Details.aspx?NewsId=2084\#sthash.G2584

Tey, N. P. (2012). Internal migration in the Klang Valley. Malaysian Journal of Chinese Studies, 1, 40-59.

Thiagarajan, P., Chakrabarty, S., \& Taylor, R. D. (2006). A confirmatory factor analysis of Reilly's role overload scale. Educational and Psychological Measurement, 6(4), 657-666. http://dx.doi.org/10.1177/0013164405282452

Tucker, L. R., \& Lewis, C. (1973). A reliability coefficient for maximum likelihood factor analysis. Psychometrika, 38(1), 1-10. http://dx.doi.org/10.1007/BF02291170

Wenzel, S. A., \& Hollenshead, C. (1998). Former women faculty Reason for leaving one research university. Washington, ERIC document service.

William, M., \& Dreher, G. (1992). Compensation systems attributes and applicant pool characteristics. Academy of Management Journal, 35(3), 435-571. http://dx.doi.org/10.2307/256487

Willis, C. (2000). Go for your goals. Working Woman, 6-7.

Wood, O. R. (1976). A research project: Measuring job satisfaction of the community college staff. Community College Review, 3, 56-64. http://dx.doi.org/10.1177/009155217600300309

$\mathrm{Xu}$, J. Y. (2008). Faculty turnover. Discipline-specific attention is warranted. Research in Higher Education, 49(1), 40-61. http://dx.doi.org/10.1007/s11162-007-9062-7

Yan, G., Yue, Y., \& Niu, M. (2015). An empirical study of faculty mobility in China. Higher Education. http://dx.doi.org/10.1007/s10734-014-9789-y

Zakaria, N. Z., Jidi, M. M., Zani, A. M., Mislan, A., \& Eshak, E. S. (2014). Job mobility among Malaysian academics: An analysis of predictors. Proceeding of the Social Sciences Research ICSSR.

Zhou, Y., \& Volkwein, J. (2004). Examining the influences on faculty departure intentions: A comparison of tenured versus non-tenured faculty at research universities using NSOPF-99. Research in Higher Education, 45(2), 139-176. http://dx.doi.org/10.1023/B:RIHE.0000015693.38603.4c 


\section{Appendix}

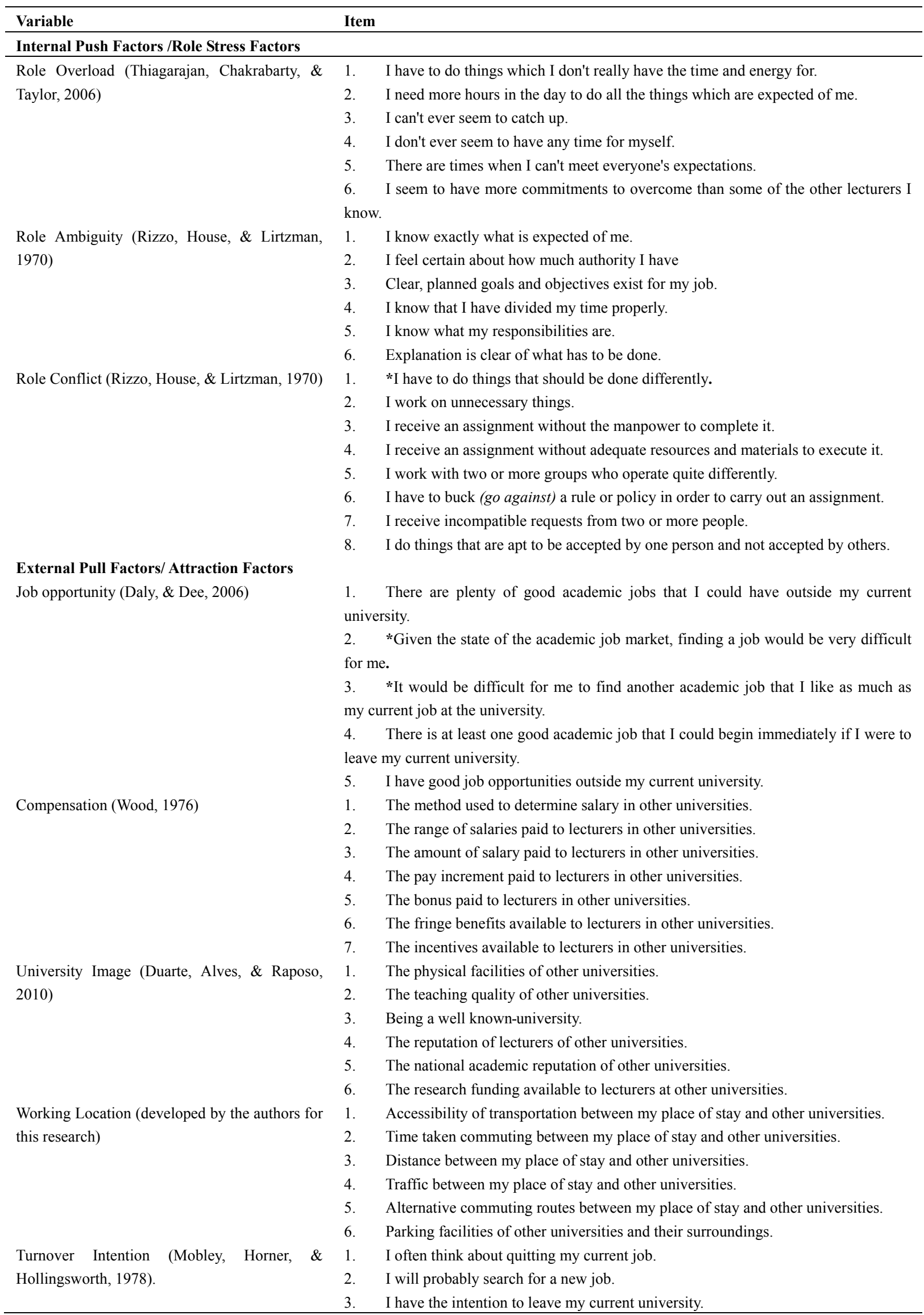




\section{Copyrights}

Copyright for this article is retained by the author(s), with first publication rights granted to the journal.

This is an open-access article distributed under the terms and conditions of the Creative Commons Attribution license (http://creativecommons.org/licenses/by/4.0/). 